\title{
Füzesi Kitti:
}

\section{A MEGÚJULÓ ENERGIAFORRÁSOK ÉS A BIZTONSÁG. VÍZERŐMÜVEK DÉL-AMERIKÁBAN: FÓKUSZBAN BRAZÍLIA}

\author{
DOI: $\underline{10.35926 / \mathrm{HSZ} .2021 .4 .10}$
}

ÖSSZEFOGLALÁS: A károsanyag-kibocsátás szemszögéből a vízenergia - számos pozitívuma mellett - fontos környezetbarát energiaforrás. Brazília, kedvező földrajzi adottságainak köszönhetöen a vízenergia hasznosítása terén a világ egyik vezető országa. Ennek ellenére, elsősorban a társadalomra gyakorolt negatív hatásai miatt a dél-amerikai országban gátépítés-ellenes mozgalmak szerveződnek. Az egyik legjelentősebb ilyen társadalmi összefogás a MAB (Movimento dos Atingidos por Barragens), amely az érintett emberek jogainak és követeléseinek érvényesitésére törekszik.

KULCSSZAVAK: Brazília, vízenergia, energia, társadalmi mozgalmak, Movimento dos Atingidos por Barragens (MAB)

\section{BEVEZETÉS}

Brazília az 1960-as évek óta számos, vízi erőművel kapcsolatos megaprojektet indított. A projektek egyrészt a megnövekedett energiaigény miatt, másrészt az importolajtól való függőség csökkentésének érdekében jöttek létre. A vízi erőmüvek működése sok esetben pozitív hatású, de az ilyen projektek kapcsán számtalan negatívumról is beszélhetünk. Környezeti szempontból például a gátak hátrányai közé tartozik az építkezéssel és magával az erőmüvel járó óriási környezeti átalakítás (pl. víztározó építése), ennek következtében az érintett területek elárasztása, a vízjárás és a halak vándorlásának megváltoztatása stb. Emellett különösen fontosak az olyan negatív társadalmi hatások, mint a földterület-kisajátítás, a lakosságkitelepítés; a bünözés, valamint a nők és gyermekek ellen elkövetett erőszak arányának növekedése az érintett területen. Ezek együttesen olyan társadalmi mozgalmakat generálhatnak, amelyek akár az adott megaprojekt megvalósítását is veszélyeztethetik.

Jelen tanulmány célja a vízenergia, a vízerőmüvek előnyeinek és hátrányainak általános bemutatása, majd Brazíliára fókuszálva a vízenergia jelenlegi helyzetének ismertetése az országon belül, többek között a brazil Eletrobras elektromos közmücég kimutatásait felhasználva. A gátak biztonsági helyzetét a brazil Nemzeti Villamosenergia Ügynökség,

\footnotetext{
Folyóiratunk szakmai mühelyébe rendszeresen érkeznek olyan tanulmányok is, amelyek nem kapcsolódnak szorosan a honvédelemhez és a Magyar Honvédséghez, azonban feldolgozható információkat tartalmaznak a biztonság tágabb összefüggésrendszerében; e körbe tartozik Füzesi Kitti dolgozata is, amely a brazil társadalmi mozgalmaknak a vízerőmüvekkel szembeni harcát ismerteti. Szerzője szakmai alma materünk, a Nemzeti Közszolgálati Egyetem Hadtudományi Doktori Iskolájának ígéretes hallgatója. Kutatási területe a hadtudományi kutatások határterületein helyezkedik el.
} 
az ANEEL (Agência Nacional de Energia Elétrica) adatai alapján járja körül. Végezetül a gátak által érintett emberek mozgalmának, a MAB-nak (Movimento dos Atingidos por Barragens) a létrejöttét, szervezeti felépítését és munkásságát mutatja be, a mozgalom vezetőivel készített interjún keresztül.

\section{A VÍZENERGIA}

A vízenergia használatának története az ókorig nyúlik vissza - a legkorábbi vízimalmok a Kr. e. I. és II. században épültek meg -, így a legrégebbi erőforrásnak számít, amit arra használtak, hogy csökkentsék az emberi és állati munkát, elsősorban a mezőgazdasági müvelés alá vont területeken. A vízben rejlő energia hasznosítása a kezdetektől fogva a villamosenergia-szolgáltatás egyik fontos szereplöje volt. ${ }^{2}$ Jelenleg ez a legszélesebb körben használt megújuló energiaforrás, a megújuló energiatermelés globális kapacitásának több mint 54\%-át teszi ki. ${ }^{3}$

Latin-Amerika kapcsán azért különösen fontos foglalkozni a vízenergiával, mert Ázsia után itt a legjelentősebb a hasznosítása; e két vezető régiót Észak-Amerika és Európa követi. A világ országait tekintve Kína található az élen (11,32 TWh - 2019), a második helyen Brazília $(3,56 \mathrm{TWh}$ - 2019) szerepel, és a képzeletbeli ranglista harmadik helyén Kanada $(3,41 \mathrm{TWh}-2019)$ áll. ${ }^{4}$

A vízenergiának számos előnyét lehet felsorolni a gazdasági, szociális és környezeti szempontokat figyelembe véve. Gazdasági szempontból a vízenergia többek között ösztönzi a regionális fejlesztéseket, optimalizálja a villamosenergia-termelés szerkezetét, erősíti az energiafüggetlenséget, valamint munkalehetőségeket teremt, ami különösen fontos például a fejlődő országokban, amelyek gyakran küzdenek alulfoglalkoztatottsági problémákkal. Társadalmi szempontból javítja az adott terület megközelíthetőségét azáltal, hogy a gátakhoz utakat, hidakat építenek; növeli a környezeti terület árvízzel szembeni biztonságát, valamint a hatalmas gátak gyakran válnak turistaattrakciókká. Végül, fontos kiemelni a környezeti szempontokat is: általa lassítható a nem megújuló energiakészletek kimerülése, csak minimális üvegházhatású gázt termel, és a károsanyag-kibocsátás szempontjából - különösen a folyami vízerőművek - segíti a klímaváltozás lassítását. ${ }^{5}$

A számos kedvező hatás mellett fontos megjegyezni, hogy a felsoroltaknak mind létezik ellenoldaluk. A vízerőmü energiatermelése nem állandó, függ az időjárástól. Aszályos években (lásd Brazíliát 2014-ben, a labdarúgó-világbajnokság esztendejében) a megtermelt villamosenergia jelentősen csökkenhet. Az építkezés tényleg munkahelyeket teremt, de csak a gát elkészültéig. A kiépített infrastruktúra pedig az illegális tevékenységek gyarapodását is segíti: az utak mentén gyakoribb az illegális fakitermelés, bányászat stb. Mindezen felül számolni kell a negatív gazdasági és szociális hatásokkal is, hiszen a projektek megvalósítása nagyon drága, esetleg külföldi hitel felvételével történik, és hosszú időt vesz igénybe mind a tervezés, mind a kivitelezés. Az erőmüvek kialakítása gyakran a lakosság áttelepítését teszi szükségessé, korlátozhatja a hajózást, megváltoztathatja a helyi földhasználati

2 Dr. Szlivka Ferenc - Dr. Molnár Ildikó: Víz- és szélenergia hasznosítás. Edutus Főiskola, 2011, 1-2.

3 The world's most used renewable power sources. Power Technology, 06. 01. 2020. https://www.power-technology. com/features/featurethe-worlds-most-used-renewable-power-sources-4160168/(Letöltés időpontja: 2020. 10. 17.)

4 BP Statistical Review of World Energy, 69 $9^{\text {th }}$ Edition, 2020, 51.

5 Szeredi István et al.: A vízenergia-hasznosítás szerepe, helyzete, hatásai. Magyar Tudomány, 2010/8., 971. 
módokat, és növelheti a vízhez köthetö járványok terjedését. ${ }^{6}$ Lerombolhat akár természeti látványosságokat, ahogy például az Itaipu-gát építése során történt. A gát megépítéséhez szükségessé vált a Paraná folyó elterelése, amit 1978-ban sikerült megvalósítani, majd megindulhattak az építési munkálatok, amelyek 1982-re elkészültek. Ezt követően a gát mögötti, több mint $1400 \mathrm{~km}^{2}$-es területet elárasztották, és egy hatalmas mesterséges tavat hoztak létre. Sajnos ennek következményeként örökre eltünt a Föld színéről egy, az Iguazú-vízeséshez hasonló természeti szépség, a Guaíra-vízesés.?

\section{Vízenergia Brazíliában}

A latin-amerikai térségben Brazília rendelkezik a legnagyobb épített vízerőmü-kapacitással. 2020-ban a villamosenergia-ellátás $66 \%$-át a vízenergia biztosította. ${ }^{8}$ Mindez az ország földrajzi adottságaiból is következik. Brazília területén található Földünk édesvízkészletének mintegy 12\%-a, ami hatalmas édesvíz-potenciált jelent. ${ }^{9}$ Tizenkét vízrajzi régióban megközelítőleg kétszázezer kisebb vízgyüjtő terület van; ilyen nagy régió például a Paraná, a São Francisco és Amazónia. ${ }^{10}$

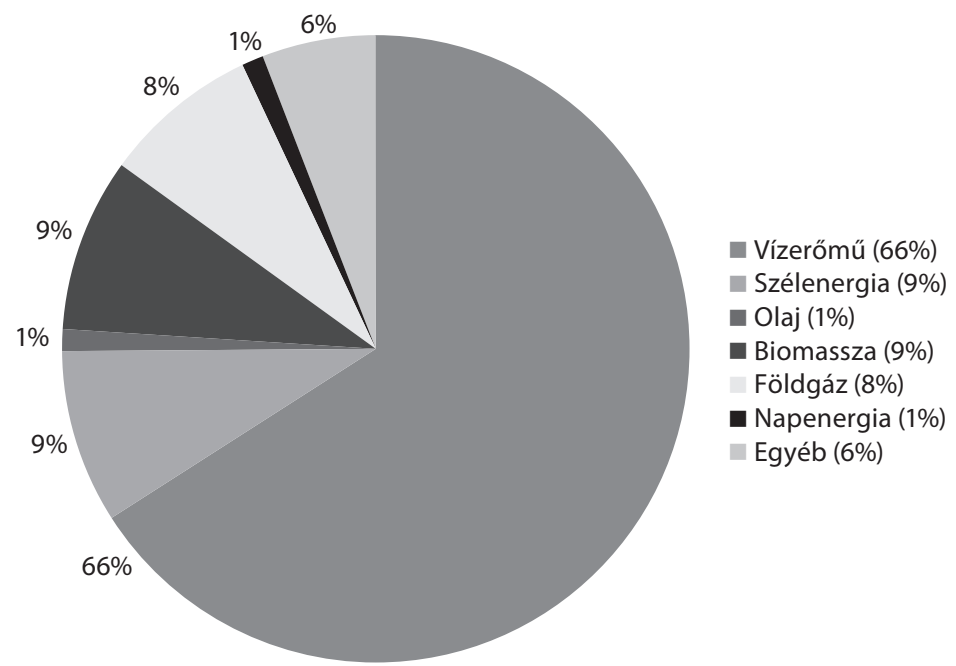

1. ábra A villamosenergia-ellátás és az egyes erőforrások megoszlása, ${ }^{11} 2020$ (Szerkesztette a szerzö)

Noha a vízenergiát már a 19. század végétől használták Brazíliában, a nagy beruházások, az erőmüvek építésének időszaka az 1960-1970-es évekre datálódik. Ennek egyik oka az erre az időszakra jellemző számottevő népességnövekedés, amelynek következményeként

\footnotetext{
${ }^{6}$ Szeredi et al.: i. m. 971.

${ }^{7}$ Andrew Nickson: The Itaipú Hydro-Electric Project: The Paraguayan Perspective. Bulletin of Latin American Research, Vol. 2, 1982/1., 6-8.

${ }^{8}$ Monthly energy bulletin Brazil. Ministry of Mines and Energy - MME, Secretariat of Energy Planning and Development - SPE, Department of Information and Studies On Energy - DIE, 04. 2020., 2.

${ }^{9}$ Ministério doMeio Ambiente: Água. https://www.mma.gov.br/agua (Letöltés időpontja: 2020. 10. 17.)

10 Uo.

11 Forrás: Monthly energy bulletin Brazil.
} 
emelkedett az energiaigény. ${ }^{12}$ Ezenkívül az 1973-as olajválság a változtatás szükségességére hívta fel az ország vezetőinek figyelmét, ugyanis Brazília az 1970-es évek elejéig alapvetően a kedvező külső feltételekre, az olcsó energiára támaszkodott. Mindezt jól mutatja, hogy az említett időszakban a kőolaj $80 \%$-át importból szerezte be. ${ }^{13}$ A katonai diktatúra idején (1964-1985) az ország vezetése fontos gazdaságélénkítő szerepet tulajdonított a vízerőmúvek építésének, így az 1970-es évek végére az ország déli és középső részén lévő jelentősebb folyók nagy részén már gátak üzemeltek.

A 21. századra azonban az új nagy erömüvek építése visszaesett, amely több okra vezethető vissza. Az ország déli, délnyugati részén már megépültek a nagy gátak, így többnyire csak kisebb projekteket lehet a régiókban megvalósítani, az új beruházások ezért elsősorban Brazília északi területére koncentrálódnak. Az Eletrobras által becsült vízenergia-potenciál tekintetében Brazília régiói közül jelentősen kiemelkedik Amazónia 98 548,67 MW teljesítménnyel, ami több mint kétszerese a délkeleti (43 723,14 MW), a déli (42 004,45 MW) és a középnyugati (39 882,64 MW), továbbá több mint négyszerese az északkeleti (22 081,83 MW) régió becsült értékeinek. ${ }^{14}$ Ezekből az adatokból kiszámolva látható, hogy az ország teljes vízenergia-potenciáljának 40\%-át Amazónia adja.

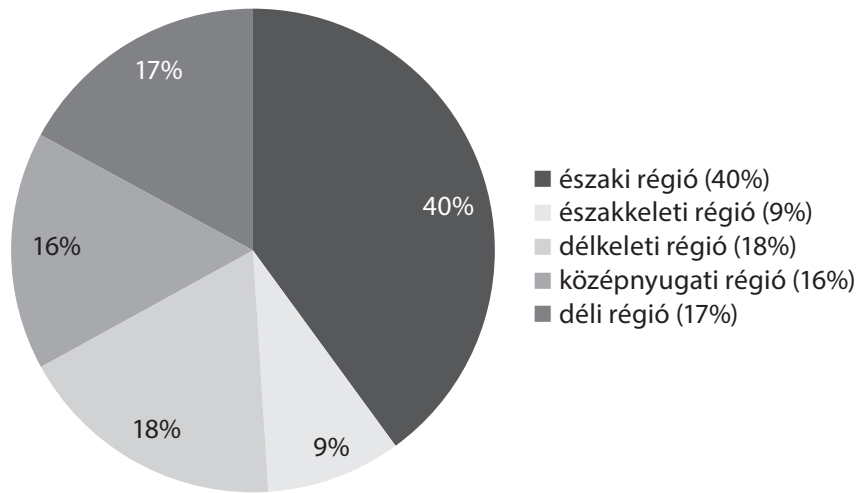

2. ábra $A$ vizenergia-potenciál megoszlása Braziliában régiónként ${ }^{15}$ (Szerkesztette a szerzö)

Ez a terület viszont messze esik Brazília sürün lakott, iparosodott, ezáltal nagy energiaigényű övezeteitől, az energia szállítása a nagy távolság miatt pedig igen költséges. További nehézséget okoz, hogy az erőmüvek építéséhez meg kell szerezni a szükséges engedélyeket, ami sokszor bonyolult, mert az építtetők nagy ellenállásba ütköznek a környezetvédelmi szervezetek részéröl. Ez azzal a veszéllyel fenyeget, hogy a befektetők inkább más energetikai ágazatba invesztálnak, így - függetlenül Brazília kedvező földrajzi adottságaitól - a vízenergetikai projektek háttérbe szorulhatnak. ${ }^{16}$

${ }^{12}$ Füzesi Kitti: Brazília és Paraguay bilaterális kapcsolatai. Felderítỏ Szemle, 18. évf. 2019/1., 96.

${ }^{13}$ Marcus Renato S. Xavier: The Brazilien Sugarcane Ethanol Experience. Competitive Enterprise Institute, Issue Analysis, 2007/3., 4.

${ }^{14}$ Potencial Hidrelétrico Brasileiro em cada Estágio por Regiões (valores em MW), Eletrobras. https://eletrobras.com/pt/ AreasdeAtuacao/geracao/sipot/Potencial\%20Hidrel\%C3\%A9trico\%20Brasileiro\%20por\%20Regi\%C3\%A3o\%20 -\%20Dezembro\%202018.pdf (Letöltés időpontja: 2020. 12. 10.)

${ }^{15}$ Forrás: Potencial Hidrelétrico Brasileiro em cada Estágio por Regiões (valores em MW), Eletrobras.

${ }^{16}$ Mateus Machado Neves: Difficulties in expanding hydropower generation in Brazil. The George Washington University - The School Of Business and Public Management - The Institute Of Brazilian Issues, Washington, 2009, 1-3. 
A 3. és 4. ábrán látható térképrészleteken - amit az Eletrobras készített 2018 végén - is jól megfigyelhető a vízenergetikai fejlesztések területi változása. A háromszögek jelölik a már elkészült erőmüveket, négyzettel szerepelnek azok a gátak, amelyekhez az engedélyeket beszerezték, a kör pedig a jövőbeli terveket mutatja. A hatszögek azokat a projekteket jelölik, amelyek a térkép készülésének idején (2018. december) leálltak, például különböző tüntetések miatt. Látható, hogy az ország déli régiójában jóval több a már elkészült vízerőmü, mint a tervezett, míg a második térképen az északi, amazóniai térségben - néhány olyan kivétellel, mint a Belo Monte - csak tervezési fázisban lévő gátak vannak.

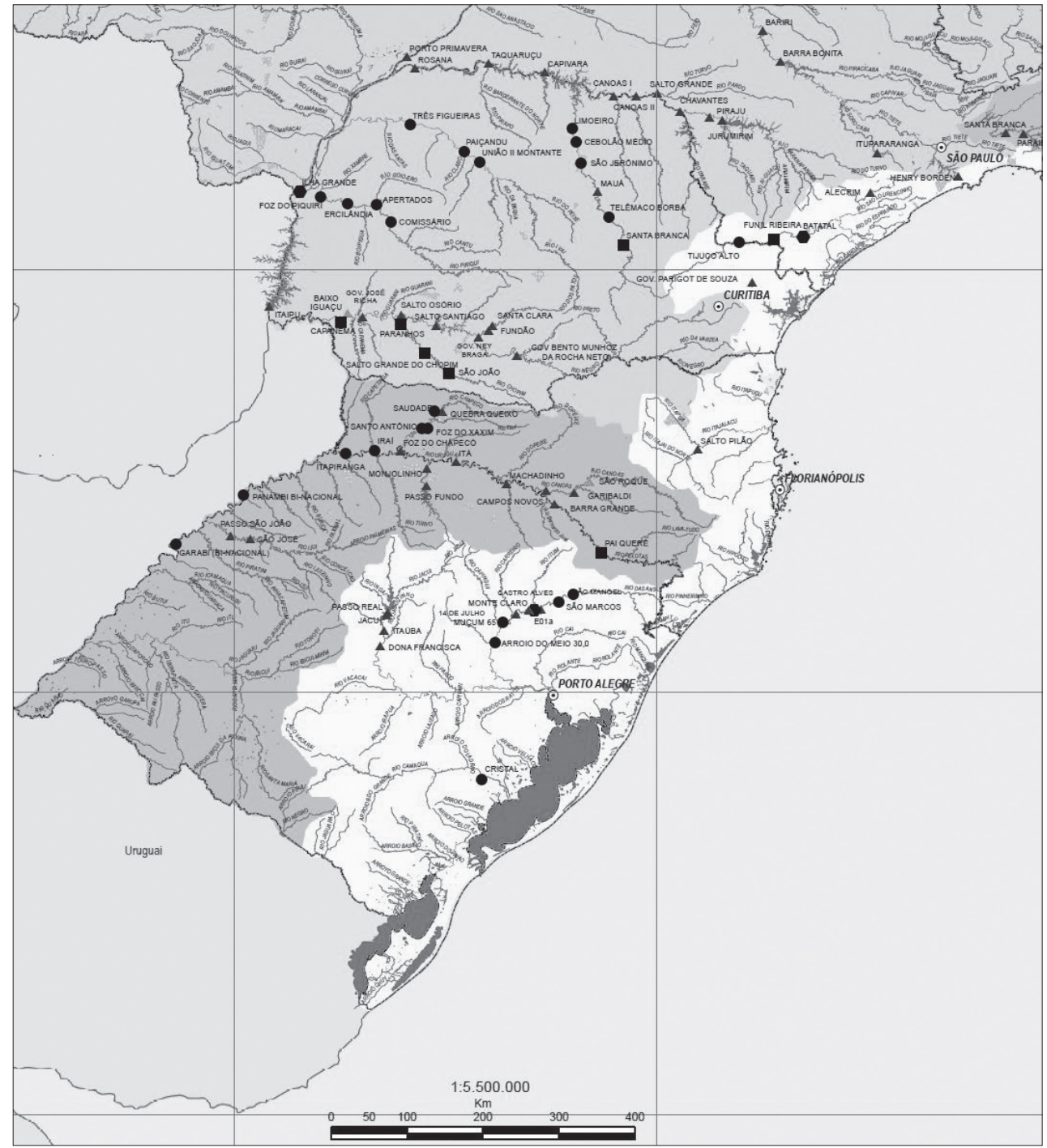

3. ábra Vizerőmüvek Brazília déli régiójában ${ }^{17}$

${ }^{17}$ Forrás: Potencial Hidrelétrico Brasileiro (SIPOT). https://eletrobras.com/pt/AreasdeAtuacao/geracao/sipot/ MapaSipot-Dezembro2018.pdf (Letöltés időpontja: 2020. 12. 10.) 


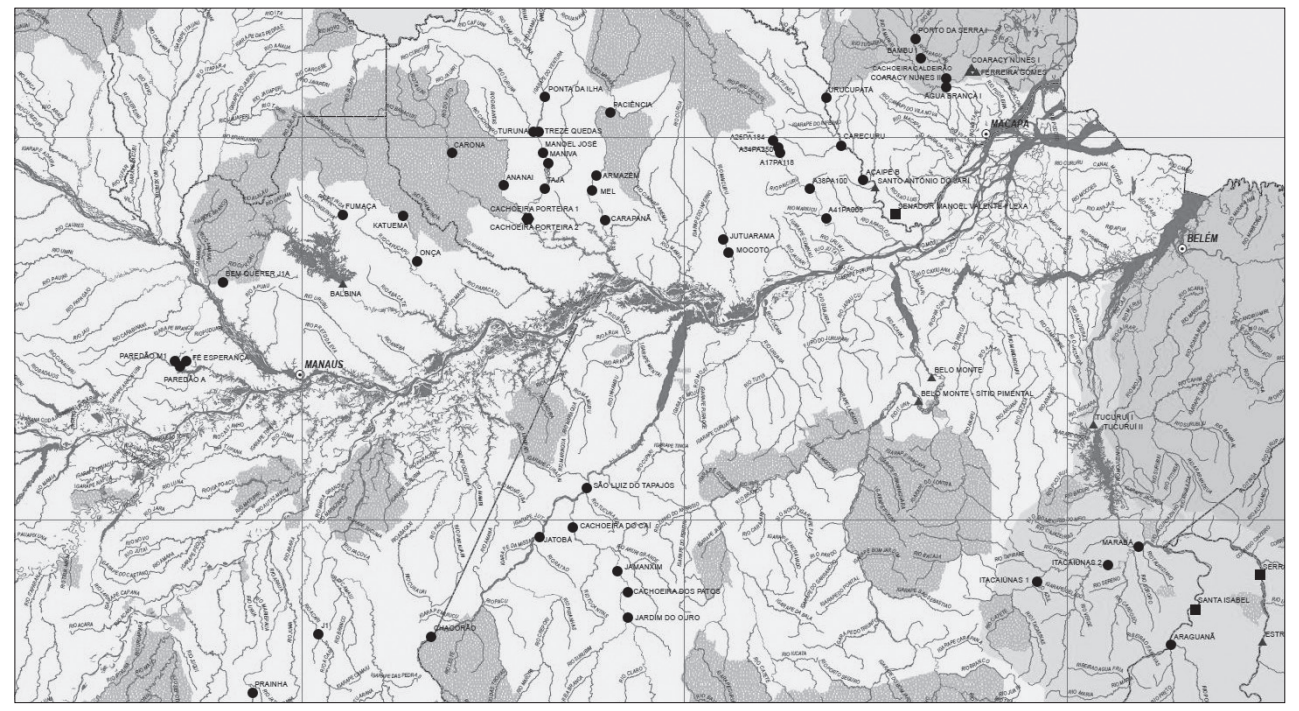

4. ábra Vizerömüvek Brazilia északi régiójában ${ }^{18}$

A legtöbb villamosenergiát öt hatalmas vízerőmü szolgáltatja: az Itaipu-gát, a Belo Monte, a São Luíz do Tapajós, a Tucuruí és a Santo Antônio. ${ }^{19}$ A hatalmas gátak mellett Brazília szorgalmazza a kisebb vízerőmüvek (pequenas centrais hidrelétricas, $P C H$ ) építését és használatát, ezek ugyanis nem járnak akkora környezeti és társadalmi beavatkozásokkal, mivel tározóterületük nem haladhatja meg a $13 \mathrm{~km}^{2}$-t, teljesítményük pedig az 5-30 MW-ot. ${ }^{20}$

\section{A GÁTAK BIZTONSÁGI OSZTÁLYOZÁSA}

2010 szeptemberében a kormány a 12.334. számú törvénnyel meghatározta a nemzeti gátbiztonsági politikát. ${ }^{21}$ A törvény célja többek között a biztonsági intézkedések szabályozása a gátak tervezése, kivitelezése és üzemeltetése során, valamint a biztonsági elöírások betartásának garantálása a megelőzés elősegítése, a balesetek, katasztrófák következményeinek és lehetőségének csökkentése érdekében. Ezenkívül a biztonsági intézkedések nyomon követését is igyekszik elősegíteni. A dokumentum 2015-ben kiegészült az ANEEL normatív határozatával, ami meghatározta a gátak besorolásának kritériumait, a rendszeres ellenőrzések és az időszakos biztonsági felülvizsgálatok feltételeit.

A gátak biztonsági osztályozása szempontjából két fő kategória különül el: a kockázati kategória és a potenciálisan okozott károk csoportja (ide azok a környezeti, társadalmi-gazdasági és az emberi életre veszélyt jelentő hatások tartoznak, amelyeket a gát esetleges sérülése nyomán kialakuló áradás okoz). ${ }^{22}$

18 Forrás: Uo.

19 Vanessa Meloni Massara: The use of hydroelectric plants in Brazil - Brief overview. MOJ Civil Engineering, Vol. 5, 2019/81.

${ }^{20}$ Uo. 81 .

${ }^{21}$ Lei N 12.334 , de 20 de Setembro de 2010. http://www.planalto.gov.br/ccivil_03/_ato2007-2010/2010/lei/112334. htm (Letöltés időpontja: 2020. 12. 15.)

${ }^{22}$ Relatório de Classificação das Barragens (Ciclo 2019). ANEEL - Agência Nacional de Energia Elétrica, 5-8. https://www.aneel.gov.br/documents/655816/14881864/Relat $\% \mathrm{C} 3 \% \mathrm{~B} 3 \mathrm{rio}+\mathrm{de}+\mathrm{Classifica} \% \mathrm{C} 3 \% \mathrm{~A} 7 \% \mathrm{C} 3 \% \mathrm{~A} 3 \mathrm{o}+\mathrm{de}$ +Seguran\%C3\%A7a+de+Barragens+-+Ciclo+2019/56cb6597-dd2b-d64a-f369-6caa3aeaf897 (Letöltés időpontja: 2020. 11. 16.) 
A kockázati kategórián belül vizsgálni és pontozni kell a technikai sajátosságokat, a védettségi állapotot és a biztonsági tervet - e három érték összege mutatja meg, hogy mekkora az esély egy nagyobb balesetre. Ha az előbbi kritériumok pontszámainak összege meghaladja a 62-t, egy gát nagy kockázatúnak, 35-62 pont között közepesnek, míg 35 pont alatt alacsony kockázatúnak számít. ${ }^{23}$ Ahogy az 5. ábrán látható, a 2019-es év felmérései alapján a Brazíliában lévő gátak döntő többsége (96\%-a) alacsony kockázatúnak számít, mindössze 28 gát szerepel a közepes kockázatúak között és egyetlen magas kockázatú gátat sem találtak. ${ }^{24}$

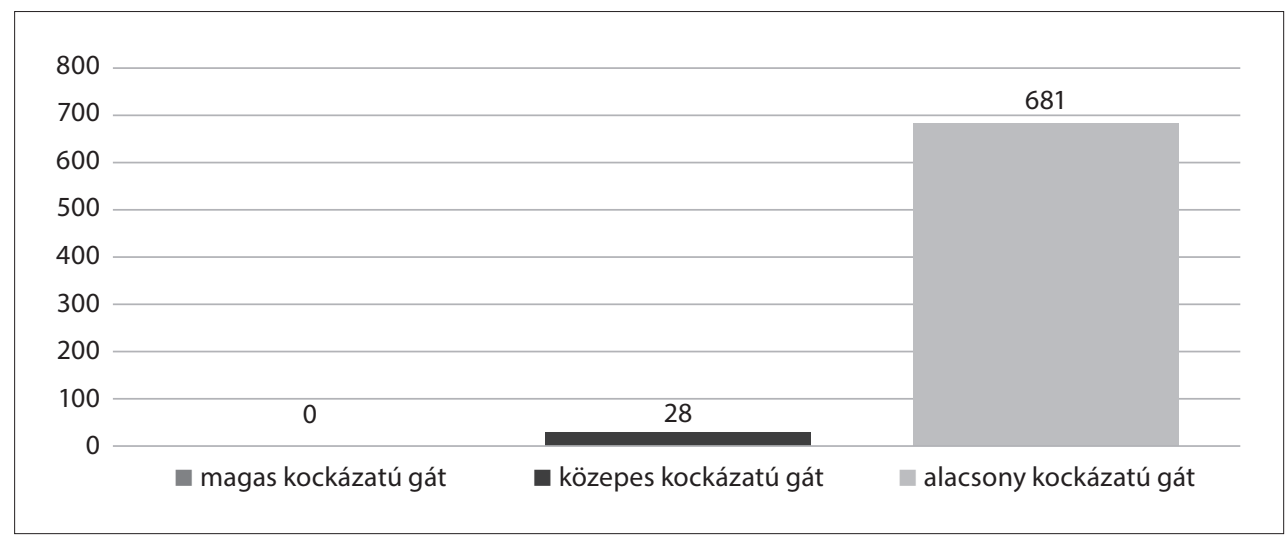

5. ábra Gátak besorolása Brazíliában a kockázati kategória alapján ${ }^{25}$ (Szerkesztette a szerzö)

A potenciálisan okozott károk esetében, ha az adott gát pontszáma eléri vagy meghaladja a 16 pontot, magas kockázatúnak, 10-16 pont között közepesnek, 10 pont alatt pedig alacsony kockázatúnak tekintendő. ${ }^{26}$

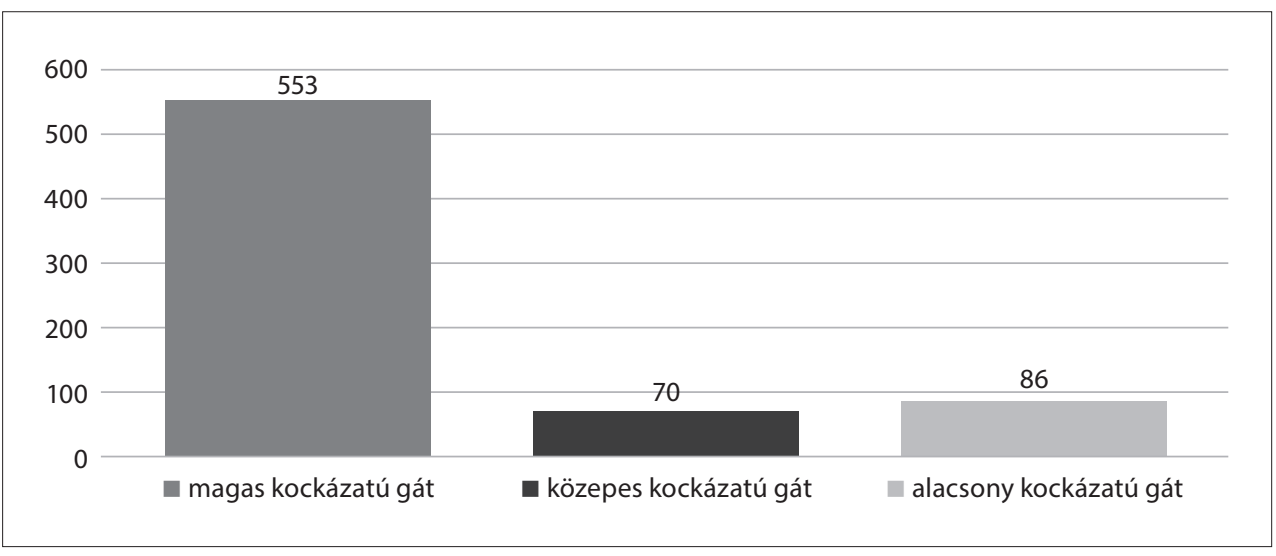

6. ábra Gátak besorolása Brazíliában a potenciálisan okozott károk alapján ${ }^{27}$ (Szerkesztette a szerzö)

\footnotetext{
23 Uo. 5-8.

${ }^{24}$ Uo. 18.

25 Forrás: Uo. 18.

${ }^{26}$ Uo. 9.

${ }^{27}$ Forrás: Uo. 18.
} 
Ezt a kategóriát összehasonlítva az előzővel, teljesen más képet kapunk az országban lévő gátakról. A potenciális károk tekintetében 78\%-uk magas kockázatúnak számít, ami abból következik, hogy Brazília gátjainak többsége a nagy vízerőmű kategóriába sorolható. Ezekhez az erőmüvekhez hatalmas méretü tározók tartoznak, amelyek lehetséges sérülései óriási veszélyt jelentenek a környezetükre. Egy esetleges áradás jelentős emberi és anyagi veszteséggel járna. Az előbbiekben felsorolt kockázati tényezők jelentős szerepet játszanak a gátak építése ellen irányuló mozgalmak megalakulásában, kibontakozásában.

2020-ban a brazil kormány új gátbiztonsági törvényt vezetett be. ${ }^{28}$ A jogszabály elöírja többek között, hogy minden közepes és magas kockázatú gát esetében el kell készíteni az úgynevezett vészhelyzeti cselekvési tervet. Ezenfelül naprakészen kell tartani a gátbiztonsági tervet, amely tartalmazza a szerkezetre, létesítményekre és berendezésekre vonatkozó müszaki adatokat, valamint az árvíztérképet. Utóbbi elkészítésének célja, hogy a gát sérülése, átszakadása esetén megkönnyítse az érintett területek kiürítését. Elöírja továbbá, hogy a gátat üzemeltetőnek a helyi védelmi szervekkel együttmüködve, meghatározott időközönként, a potenciálisan érintett lakossággal együtt a gát sérülésének esetére érvényes vészhelyzeti szimulációs gyakorlatot kell végeznie. ${ }^{29}$

\section{TÁRSADALMI MOZGALMAK BRAZÍLIÁBAN}

A gazdasági fejlödéssel összefüggésben Latin-Amerikában - azon belül Brazíliában is az emelkedő energiaigény kielégítésében fontos szerepet játszanak a vízerőmüvek; a megaprojektek azonban gyakran erős társadalmi ellenállást gerjesztenek. Az érintett terület lakosai mellett környezetvédelmi csoportok, ökológusok, nem kormányzati szervezetek (NGO-k) kapcsolódhatnak be a mozgalmakba, ami akár nemzetközivé is válhat. A legnagyobb ellenvetést általában a lakosság kitelepítése váltja ki. ${ }^{30}$

2000 és 2017 között a dél-amerikai országban összesen 8,8 millió ${ }^{31}$ embernek kellett elhagynia otthonát. A legtöbbjük (73\% - mintegy 6,4 millió fö) ${ }^{32}$ valamilyen (például természeti) katasztrófa miatt kényszerült lakóhelyéröl elköltözni. A hivatalos statisztika csak 6047 embert említ, akiknek a gátak sérülése, leomlása miatt kellett távozniuk. ${ }^{33}$ Az elvándorlás-kitelepítés második leggyakoribb okai az új fejlesztések, illetve projektek, amelyek több mint 1,29 millió embert érintettek Brazíliában. Ezek közé tartoznak a vízerőmúvek is. ${ }^{34} 2000$ és 2017 között több mint nyolcvan gát épült meg, aminek következményeként 150-240 ezer állampolgárnak kellett elhagynia otthonát vagy földjeit. ${ }^{35}$ Pontos, hivatalos adat nincs arról, hogy a gátak építése összesen hány embert érint a dél-amerikai országban,

${ }^{28}$ Az új törvény bevezetésében szerepet játszott a 2015-ös marianai és a 2019-es brumadinhói gát átszakadása.

${ }^{29}$ Lei N 14.066 , de 30 de Setembro de 2020. https:/www.in.gov.br/en/web/dou/-/lei-n-14.066-de-30-de-setembrode-2020-280529982 (Letöltés idöpontja: 2020. 12. 18.)

30 Anahí Gómez et al.: Resistencias sociales en contra de los megaproyectos hídricos en América Latina. European Review of Latin American and Caribbean Studies, 2014, No. 97, 76-77.

31 Maiara Folly: Migrantes invisíveis: a crise de deslocamento forçado no Brasil. Instituto Igarapé, Artigo Estratégico 2018, No. 29, 2.

32 Uo. 10 .

33 Uo. 20.

${ }^{34}$ Uo. 10

35 Tempering the human cost of building Brazil's dams. Instituto Igarapé, 29. 06. 2017. https://igarape.org.br/en/ tempering-the-human-cost-of-building-brazils-dams/ (Letöltés időpontja: 2020. 11. 13.) 
de a MAB (Movimento dos Atingidos por Barragens - Gátak által érintett emberek mozgalma) becslése szerint ez a szám körülbelül 1,5 millió főre tehető. ${ }^{36}$

A társadalmi mozgalmak szerveződésében, sikerében és intenzitásában fontos szerepet játszik az ország politikai berendezkedése. 1964 áprilisára Brazília irányítása már a hadsereg kezében volt, s az országot két évtizeden át diktatórikus rendszer jellemezte. ${ }^{37}$ Ebben az időszakban a kormányzat könnyen véghez tudta vinni a vízenergetikai projektjeit, mivel nem kellett környezetvédelmi hatásvizsgálatot végeztetni, továbbá nem tartották szem elött a gátak környezetében élő őslakosok, földmüvesek megélhetését és érdekeit. Az ország vezetésének ellenállástól sem kellett tartania, hiszen a polgári jogok és a demokratikus intézmények nagymértékben korlátozottak voltak. ${ }^{38}$

A katonai diktatúra lazulásával, majd végével Brazília számos pontján a gátak építése ellen mozgalmak szerveződtek. 1987-ben megtartották a gátak által érintett emberek első országos találkozóját, 1991 márciusában pedig az első országos kongresszusát. A kongresszus zárónapját, március 14-ét a gátak elleni harc nemzeti napjává nyilvánították, amit azóta is minden évben megtartanak az országban. ${ }^{39}$ Hat évvel később, a szintén Brazíliában megrendezett, gátak által érintett emberek első világtalálkozóján a részt vevő 20 ország képviselői ${ }^{40}$ március 14 -ét gátellenes világnappá nyilvánították. ${ }^{41}$

Az 1980-as évek végén, a 90-es évek elején a gazdasági válság miatt a nagy beruházások száma csökkent, ezzel összefüggésben a tüntetések intenzitása is alábbhagyott. Fernando Henrique Cardoso elnöksége alatt (1995-2003) privatizálták az energiaszektort, ami lehetőséget adott a külföldi befektetések növekedésére, így a vízenergetikai beruházások száma is emelkedett és egyre inkább a magánvállalatok kezébe került át. A vízerőmüvek, vízenergetikai fejlesztések Lula da Silva elnöksége idején (2003-2011) is központi szerepet játszottak, ezt jól mutatja, hogy elnöksége alatt a Kongresszus rekordgyorsasággal fogadta el a Belo Monte-gát építését. ${ }^{42}$ Michel Temer elnöksége alatt (2016-2018) csökkent a vízenergetikai megaprojektekbe történő beruházások száma. ${ }^{43}$ A Jair Bolsonaro vezette brazil kormány (2019-) pedig elsősorban a kisebb vízerőművek építését szorgalmazza. ${ }^{44}$

${ }^{36}$ Portugál nyelvű írásos interjú a MAB egyik képviselőjével. 2020. 12. 03. (A továbbiakban: MAB-interjú.)

37 Egyszemélyi diktatúráról azonban nem beszélhetünk, hiszen a húsz év alatt nem egyetlen ember irányította a dél-amerikai országot, hanem tábornokok váltották egymást az elnöki poszton, akik rendeletekkel kormányoztak.

${ }^{38}$ Kjersti Thorkildsen: 'Land yes, dam no!' Justice-seeking strategies by the anti-dam movement in the Ribeira Valley, Brazil. The Journal of Peasant Studies, 2016, 1.

39 Movimento dos Atingidos por Barragens, I. Congresso Nacional Dos Atingidos Por Barragens. https://mab.org.br/ tmeline/i-congresso-nacional-dos-atingidos-por-barragens/ (Letöltés időpontja: 2020. 10. 20.)

40 Többek között a részt vevő államok: Argentína, Brazília, Chile, Franciaország, Lesotho, Oroszország, Svájc, Tajvan, Thaiföld, USA. 14 March - International Day for Rivers. https:/www.rivernet.org/general/movement/14mars. htm (Letöltés időpontja: 2020. 12. 16.)

${ }^{41}$ International Day of Action for Rivers, March 14! International Rivers, People, Water, Life. https://www. internationalrivers.org/take-action/international-day-of-action-for-rivers/ (Letöltés időpontja: 2020. 11. 10.)

${ }^{42}$ Heidi Michalski Riberio - Jose Rubens Morato: Social environmental injustices against indigenous peoples: The Belo Monte dam. Disaster Prevention and Management, 2020, 6.

43 David J. Hess: The anti-dam movement in Brazil: expertise and design conflicts in an industrial transition movement. Tapuya: Latin American Science, Technology and Society, 2018, 260-262.

${ }^{44}$ Bolsonaro declara que vai agilizar a instalação de PCHs. ABRAPCH - Associação Brasileira de Pequenas Centrais Hidrelétricas (PCHs) e Centrais Geradoras Hidrelétricas (CGHs). https://abrapch.org.br/2020/02/07/bolsonarodeclara-que-vai-agilizar-a-instalacao-de-pchs/ (Letöltés időpontja: 2020. 10. 24.) 


\section{A GÁTAK ÁLTAL ÉRINTETT EMBEREK MOZGALMA (MAB)}

A MAB az 1980-as évek végén, a katonai diktatúra bukása után, a demokratikus időszak kezdetén indult el. Jelszava: „A víz és az energia nem árucikk." 45 Elindításában fontos szerepet játszott, hogy a gátak által érintett emberek úgy vélték, saját, helyi érdekeik védelmén kívül fel kell lépni az országban uralkodó energiamodell ellen is, ehhez pedig egy szélesebb körü szervezet létrehozására volt szükség. Ennek jegyében 1989-ben került sor a gátak által érintett munkavállalók első, országos találkozójára, ahol megfogalmazták egy országos szervezet létrehozásának igényét, amely képes a hatékony érdekérvényesítésre. Az 1991-ben megtartott első kongresszus döntése alapján a MAB-nak országos, autonóm mozgalomnak kellett lennie, legfőbb feladata pedig a célok megfogalmazása és a gátak ellen irányuló akciók megszervezése volt. Ezt követően a MAB háromévente kongresszusokat tartott, amelyeken a régiók képviselöi vettek részt, és az itt meghozott döntések szolgáltak az akciók iránymutatásaiként. ${ }^{46}$

A mozgalom számára nagy jelentőségű volt, hogy 2009-ben Lula da Silva elnök először ismerte el: a brazil államnak adóssága van a gátak által érintett emberek felé, és ígéretet tett arra, hogy ezt a problémát elnöksége alatt rendezni fogja. Bár az ország történelme során elöször ismerte el egy államfö a szervezet munkáját és az érintett emberek jogos követeléseit, változás azóta sem következett be, a gondokat nem sikerült megoldani. ${ }^{47}$

2011 áprilisában a fóvárosban tartották meg a gátak által érintett nők első találkozóját, amin ötszázan vettek részt. A találkozón az őket ért erőszak és az általuk folytatott küzdelem volt a fö téma. ${ }^{48}$ A nők a MAB létrejöttétől kezdve fontos szerepet játszottak a mozgalom építésében. 2007 és 2010 között számos regionális találkozóra került sor, amelyeknek az volt a céljuk, hogy megismerjék a gátak építésének nőkre gyakorolt hatásait. Az őket ért leggyakoribb jogsértések a munkához, a politikai részvételhez, valamint a szexuális és reproduktív jogokhoz kapcsolódnak. ${ }^{49}$

Brazíliában jelenleg a MAB a legfontosabb gátellenes szervezet: a dél-amerikai ország 26 tagállamából 19-ben van jelen. Központja a fővárosban található, képviselői az ország számos pontját bejárják, hogy a gátak által érintettek csoportosulásait bevonják a mozgalomba. Szervezeti felépítését tekintve több szintre tagolódik: országos, tagállami, regionális és önkormányzati szintre, valamint lokálisan egy-egy gáthoz kapcsolódva. ${ }^{50}$ Tapasztalatcseréket, közösségi találkozókat kezdeményez a gátak által veszélyeztetett emberek körében, igyekszik növelni a helyi lakosság részvételét a környezeti meghallgatásokon, valamint eröszakmentes tiltakozásokat, akciókat szervez. ${ }^{51}$

45 Água e energia não são mercadorias.

46 The history of MAB. Movimento dos Atingidos por Barragens, 26. 03. 2011. https://mab.org.br/2011/03/26/ history-mab/ (Letöltés időpontja: 2020. 11. 12.)

47 Pela primeira vez, fomos reconhecidos enquanto atingidos por um presidente. https://mab.org.br/timeline/pelaprimeira-vez-fomos-reconhecidos-enquanto-atingidos-por-um-presidente/ (Letöltés időpontja: 2020. 11. 16.)

48 I. Encontro das Mulheres Atingidas por Barragens. https://mab.org.br/timeline/i-encontro-das-mulheres-atingidaspor-barragens/ (Letöltés időpontja: 2020. 11. 16.)

49 Sobre as Mulheres Atingidas por Barragens. https://mab.org.br/mulheres/ (Letöltés időpontja: 2020. 11. 16.)

50 MAB-interjú.

${ }^{51}$ Sabrina McCormick: The brazilian anti-dam movement. Knowledge Contestation as Communicative Action, Organization \& Environment, Vol. 19, 2006/3., 331-333. 


\section{A MAB célkitǔzései}

„Az 1990-es évekig Brazíliában a villamosenergia-ágazat teljes egészében állami tulajdonban volt, így a küzdelem egyet jelentett az állami vállalatokra, minisztériumokra és kormányzati szervezetekre való nyomásgyakorlással. Az ezt követő privatizáció eredményeként az energiaszektort a nemzetközi pénzügyi tőke kezdte irányítani, s ez a strukturális változás nagyobb kihívás elé állította a MAB-ot. A küzdelem azóta az érintett lakosság jogainak garantálása és a profitorientált vállalatok érdekei között zajlik." ${ }^{52}$ Erre reagálva alakult át a mozgalom fö célkitüzése, amely - az érintett emberek jogainak elismerése és garantálása mellett - arra törekszik, hogy apránként megváltoztassa a brazil energiamodellt, mert azt a MAB szerint nem a lakosság szükségleteinek megfelelően alakították ki. Fontosnak tartják továbbá az energiaárak csökkentését, amit az ország kedvező energetikai helyzete szerintük lehetővé is tenne. Ehhez egy új társadalmi berendezkedésre lenne szükség, amelyben nem a nemzetközi vállalatok a gazdaság fő szereplői, hanem jobban figyelembe veszik az állampolgárok igényeit is. ${ }^{53}$ Jelszavuk, hogy a víz és az energia az emberek szuverén joga, és harcolnak azért, hogy a vállalatok ne a polgárok kárára akarjanak nyereséghez jutni. ${ }^{54}$

Kettősség figyelhető meg Brazília demográfiai adataiban, hiszen az Atlanti-óceán partvidéke sürün lakott, nagyvárosokkal rendelkező, iparosodott terület, míg a kontinens belső része felé haladva egyre ritkábban lakott a vidék, ahol a bennszülött lakosság jelentős része él. ${ }^{55}$ A kétarcúság a gazdasági fejlettségben is megmutatkozik: az ország déli, délkeleti területei jóval fejlettebbek, iparosodottabbak az északi, északkeleti térségekhez képest. ${ }^{56}$ Ez a kettősség jellemző az energiaigényre is: míg az előbbi sok villamosenergiát használ, addig az utóbbi területek vannak leginkább közel a vízerőművek építési területeihez. Így a MAB tevékenysége nemcsak a gátellenes tüntetésekre terjed ki, hanem segítséget nyújt a már elkészült erőmüvek által érintett emberek kártérítésének ügyeiben, akik sok esetben nem tudnak önállóan kiállni a jogaikért. ${ }^{57}$ Ügyel arra, hogy az építkezések során a vállalkozások igyekezzenek mérsékelni az okozott károkat például azzal, hogy utakat, kórházakat, iskolákat építenek. ${ }^{58}$

\section{A gátépítés legfontosabb negatív társadalmi hatásai}

A MAB a gátépítés negatívumai közül nem a környezeti, hanem a társadalmi hatásokat emeli ki. A mozgalom véleménye szerint ,,az egyik legnagyobb negatívum az érintett lakosság részvételének hiánya. Ráadásul az érintett közösségek strukturálatlanok, ezért nincsenek felkészülve arra, hogy érveiket olyan módon tudják felépíteni és képviselni, amellyel garantálni tudnák a jogaikat" ${ }^{59}$ A brazil jogalkotás nagy hiányossága, hogy nincs egy egységesen elfogadott szabályozási keret vagy politika, ami foglalkozna az érintettek jogaival, emiatt van fontos szerepe a mozgalomnak.

\footnotetext{
52 MAB-interjú.

53 Uo.

54 Lutas, Movimento dos Atingodos por Barragens. https://mab.org.br/lutas/ (Letöltés időpontja: 2020. 11. 16.)

55 Soltész Béla: Brazília. In: Szente-Varga Mónika - Bács Zoltán György (szerk.): Dél-Amerika a 21. században Társadalmi, gazdasági és politikai konfliktusok. Dialóg Campus Kiadó, Budapest, 2019, 41.

56 Szente-Varga Mónika: Brazília az olimpia előtt. Nemzet és Biztonság, 2016/3., 112.

${ }^{57}$ Hess: i. m. 258-260.

58 Gómez et al.: i. m. 81.

59 MAB-interjú.
} 
A társadalomra gyakorolt negatív hatásként emelhetö ki a bünözés - különösen az eröszakos büncselekmények - megnövekedése a vízerömüvek építési területének közelében. Az építkezésekre nagyszámú férfi munkaerő érkezik az ország különböző pontjaiból, ennek következtében a nők, fiatalok és gyermekek elleni szexuális erőszak mértéke nagyarányú növekedést mutat; az érintett közösségben tapasztalt kiszolgáltatott helyzet által generált feszültség miatt növekszik a családon belüli erőszak gyakorisága; emellett jelentős a gátak elleni aktivistákkal szemben elkövetett eröszak is.

Az erőszak több esetben is a mozgalmi vezetők meggyilkolásában nyilvánult meg, ${ }^{60}$ például 2016-ban, amikor Nilce „Nicinha” de Souza Magalhãest, a MAB egyik vezetőjét ölték meg. ${ }^{61}$ Az ügyben a brazil fővárosi esküdtszék 2017 márciusában hozott ítéletet, amelyben az elkövetőt, Edione Pessoa da Silvát tizenöt és fél év börtönre ítélték. ${ }^{62}$ A MAB azonban továbbra is úgy érzi, hogy a valódi okokra még mindig nem derült fény. ${ }^{63}$ Gyilkosság áldozata lett 2019-ben Dilma Ferreira Silva aktivista és családja is. ${ }^{64}$

\section{Nemzetközi kapcsolatok}

Brazília jelentőségét a gátellenes küzdelemben jól mutatja, hogy 1997 márciusában Curitiba városában tartották a gátak által érintett emberek első nemzetközi találkozóját. A MAB fontos szerepet vállalt az esemény megszervezésében. Elsődleges céljuk olyan nemzetközi összefogás létrehozása volt, amely által hatékonyan fel tudnak lépni a világ számos pontján épülő vízerőmúvek káros hatásaival szemben. ${ }^{65}$ 2003-ban Thaiföldön, 2010-ben pedig Mexikóban került megrendezésre a nemzetközi találkozó, ahol ismételten megerősítették elkötelezettségüket az érintett emberek jogaiért való küzdelemben, illetve hangsúlyozták a nemzetközi figyelem felkeltésének fontosságát. A gátak által érintett emberek nemzetközi találkozójának növekvő jelentőségét jól mutatja, hogy a 2010-es eseményen már 60 ország 320 delegáltja vett részt. ${ }^{66}$

1999-ben São Paulóban 12 latin-amerikai ország részvételével regionális fórumot tartottak, ahol létrehozták a REDLAR-t (Red Latinoamericana contra las Represas y por los Ríos, sus Comunidades y el Agua), ami a gátak elleni, valamint a folyók és a folyami közösségek számára alapított latin-amerikai érdekvédelmi hálózat. Létrejöttében fontos szerepet játszott

${ }^{60}$ Uo.

${ }^{61}$ Nicinha 2016. január 7-én tünt el, január 15-én Edione Pessoa da Silva beismerte a meggyilkolását. Holtteste csak mintegy öt hónappal később került elő. Case History: Nilce de Souza Magalhães. Frontline Defenders. https:// www.frontlinedefenders.org/es/case/Case-History-Nilce-de-Souza-Magalhaes (Letöltés idöpontja: 2020. 12. 18.)

${ }^{62}$ Toni Francis: Acusado de matar Nicinha em Rondônia é condenado a 15 anos. http://g1.globo.com/ro/rondonia/ noticia/2017/03/acusado-de-matar-nicinha-em-rondonia-e-condenado-15-anos.html (Letöltés időpontja: 2020. 12. 18.)

${ }^{63} 3$ Anos Sem Nicinha E Sem Justiça! https://mab.org.br/2019/02/11/3-anos-sem-nicinha-e-sem-justi/ (Letöltés időpontja: 2020. 12. 18.)

${ }^{64}$ Carol Schachet: Say Their Names: Sajed Mizher, Presente. Grassroots International. https:/grassrootsonline.org/ blog/say-their-names-sajed-mizher-presente/ (Letöltés idöpontja: 2020. 12. 10.)

${ }^{65}$ Uniyal Mahesh: First international meet of anti-dam movements. Inter Press Service News Agency - North America, 1997, 1-2.

${ }^{66}$ III. Encontro Internacional dos Atingidos por Barragens. https://mab.org.br/timeline/iii-encontro-internacionaldos-atingidos-por-barragens/ (Letöltés időpontja: 2020. 11. 16.) 
a MAB megalakulása és müködése. ${ }^{67}$ A REDLAR célja egy olyan energiamodell elömozdítása, amelyben az emberek igényeit fontosabbnak tartják a globális piaci érdekeknél, ahol az energia elsősorban nem árucikk, hanem az emberek alapvető joga. ${ }^{68}$

Ezenkívül a MAB hozzájárult a gátak által érintett emberek latin-amerikai mozgalmának, a MAR-nak (Movimiento de Afectados por Represas) 2016-os létrejöttéhez. A MAB továbbra is aktívan részt vesz a latin-amerikai találkozókon, ahol a tapasztalatcseréken túl az egyes országok energiamodelljének elemzése, megvitatása a cél. Nemcsak a saját régiójában tevékenykedik, hanem kapcsolatokat ápol az Amerikai Egyesült Államokkal és Európával is, valamint segíti az afrikai kontinensen élők hasonló szerveződését. ${ }^{69}$

\section{ÖSSZEGZÉS}

Dél-Amerika kedvező földrajzi adottságai lehetővé teszik, hogy vezető szerepet töltsön be a megújuló energia használatában. E piac tekintetében a régió a világ egyik legdinamikusabban fejlödő térsége, különösen a víz-, a napenergia és a bioüzemanyag használatát illetően. ${ }^{70}$ Brazília a világelsők között szerepel a vízenergia hasznosításában, amelyhez nagymértékben hozzájárul, hogy a világ édesvízkészletének 12\%-a itt található. Az ország villamosenergia igényének több mint felét a gátak által termelt vízenergia adja. Több száz gát müködik a dél-amerikai államban, amelyek biztonsági felülvizsgálatához hatékony rendszerre volt szükség. A 2010-ben bevezetett törvénnyel, majd a 2015-ös határozattal a vízerőmüvek rendszeresen szigorú ellenőrzéseken esnek át, amelyek két kategóriát vizsgálnak. A felmérések alapján elmondható, hogy Brazília gátjainak jelentős része biztonsági szempontból alacsony kockázatúnak számít. Mivel az ország vízerömüveinek többsége nagy gát, a potenciálisan okozott károk esetében többségük nagy kockázatúnak nevezhető. Ez a tény, valamint a társadalomra és a környezetre gyakorolt negatív hatások hozzájárulnak az olyan társadalmi mozgalmak kibontakozásához, amelyek a vízi erömüvekkel szemben léptek fel Brazíliában.

Brazília a világ 5. legnagyobb országa, óriási távolságokkal, kulturális és etnikai sokszínüséggel, ráadásul a világ egyik legegyenlőtlenebb társadalma is, milliók élnek szegénységben, főként a vidéki területeken. ${ }^{71}$ Bár a gátak elleni társadalmi mozgalmak a katonai diktatúra vége felé kezdtek egyre nagyobb számban megjelenni, épp az ország méretéböl, társadalmi és kulturális helyzetéből adódóan elengedhetetlen volt egy olyan, régiók és a brazil államok felett álló szervezet létrehozása, amely hatékony érdekérvényesítéssel rendelkezik. Ezért jött létre az 1980-as évek végén a MAB, amely a legjelentősebb gátellenes társadalmi mozgalomnak számít Brazíliában, sőt fontos nemzetközi kapcsolatokkal rendelkezik, elsősorban Dél-Amerikában. A szervezet célja a gátak által érintett emberek jogainak védelme, érdekeinek érvényesítése. A MAB a gátépítés-ellenes mozgalmat leginkább társadalmi kérdésként határozza meg, a saját földhöz és az ingyenes vízhez való jogként,

\footnotetext{
${ }^{67}$ Az alapító országok Argentína, Brazília, Chile, Kolumbia, Costa Rica, Ecuador, El Salvador, Guatemala, Honduras, Mexikó, Panama és Paraguay voltak, később csatlakozott még Peru, Venezuela, Bolívia, Kuba, Nicaragua, Uruguay és Belize is. Gómez et al.: i. m. 81-83.

${ }^{68}$ Declaración del Petén, V Encuentro de la red latinoamericana contra represas y por los ríos, sus comunidades y el agua. http://radiomundoreal.fm/7166-declaracion-del-peten?lang=es (Letöltés időpontja: 2020. 11. 15.)

69 MAB-interjú.

${ }^{70}$ Adilson de Oliveira: Energy Security in South America. The role of Brazil. Series on Trade and Energy Security. International Institute for Sustainable Development, Winnipeg, Canada, 1-2.

71 Soltész: i. m. 41-49.
} 
a nagy nemzetközi „,kizsákmányoló” vállalatok ellen. Nyilván az említett társadalmi háttér miatt a gazdagok ellen való fellépés sokkal inkább mozgósító erejü, mint például a természeti kincs megőrzésére irányuló törekvés.

Bár a MAB harmicéves fennállása óta számos pozitívumról tud beszámolni. Sikerült elérni olyan megállapodásokat, amelyek lehetővé tették az érintettek jogainak elismerését, ám még mindig hiányzik a jogi háttér megteremtése, amely nem egyszerü feladat a 26 tagállamra széttagolt Brazíliában. Talán érdemes lenne más országok példáját is tanulmányozni, akár a régión belül, hiszen Brazília földrajzi kiterjedésével egyedinek tekinthető. A gátellenes mozgalmak sorra jelennek meg Dél-Amerikában, és több-kevesebb sikerrel tudnak fellépni a vízenergetikai megaprojektek ellen, annak ellenére, hogy a gátak a károsanyag-kibocsátás szempontjából az egyik leginkább környezetbarát megoldásnak tekinthetők. Felmerül a kérdés, hogy milyen hasonlóságai és különbségei vannak a gátellenes mozgalmaknak, és milyen folyamat vezet el addig, amíg a társadalom politikai szintre tudja emelni a vízerőmüvek kérdését.

\section{FELHASZNÁLT IRODALOM}

I. Encontro das Mulheres Atingidas por Barragens. https://mab.org.br/timeline/i-encontro-das-mulheres-atin gidas-por-barragens/

III. Encontro Internacional dos Atingidos por Barragens. https://mab.org.br/timeline/iii-encontro-inter nacional-dos-atingidos-por-barragens/

3 Anos Sem Nicinha E Sem Justiça! https://mab.org.br/2019/02/11/3-anos-sem-nicinha-e-sem-justi/ 14 March - International Day for Rivers. https://www.rivernet.org/general/movement/14mars.htm Bolsonaro declara que vai agilizar a instalação de PCHs. ABRAPCH - Associação Brasileira de Pequenas Centrais Hidrelétricas (PCHs) e Centrais Geradoras Hidrelétricas (CGHs). https://abrapch.org.br/ 2020/02/07/bolsonaro-declara-que-vai-agilizar-a-instalacao-de-pchs/

BP Statistical Review of World Energy, 69 ${ }^{\text {th }}$ edition, 2020.

Case History: Nilce de Souza Magalhães, Frontline Defenders. https:/www.frontlinedefenders.org/es/case/ Case-History-Nilce-de-Souza-Magalhaes

Declaración del Petén, V Encuentro de la red latinoamericana contra represas y por los ríos, sus comunidades y el agua. http://radiomundoreal.fm/7166-declaracion-del-peten?lang=es

Folly, Maiara: Migrantes invisiveis: a crise de deslocamento forçado no Brasil. Instituto Igarapé - Artigo Estratégico, 2018/ 29., 1-43.

Francis, Toni: Acusado de matar Nicinha em Rondônia é condenado a 15 anos. http://g1.globo.com/ro/ rondonia/noticia/2017/03/acusado-de-matar-nicinha-em-rondonia-e-condenado-15-anos.html

Füzesi Kitti: Brazília és Paraguay bilaterális kapcsolatai. Felderítő Szemle, 18. évf. 2019/1., 86-105.

Gómez, Anahí - Wagner, Lucrecia - Torres, Beatriz - Martín, Facundo - Rojas, Facundo: Resistencias sociales en contra de los megaproyectos hídricos en América Latina. European Review of Latin American and Caribbean Studies, 2014/ 97., 75-96.

Hess, David J.: The anti-dam movement in Brazil: expertise and design conflicts in an industrial transition movement. Tapuya: Latin American Science, Technology and Society, 2018, 256-279. DOI: 10.1080/25729861.2018.1548160

International Day of Action for Rivers, March 14, International Rivers, People, Water, Life. https:// www.internationalrivers.org/take-action/international-day-of-action-for-rivers/

Lei N 12.334 , de 20 de Setembro de 2010. http:/www.planalto.gov.br/ccivil_03/_ato2007-2010/2010/ lei/112334.htm 
Lei $N^{o}$ 14.066, de 30 de Setembro de 2020. https://www.in.gov.br/en/web/dou/-/lei-n-14.066-de-30-desetembro-de-2020-280529982

Lutas, Movimento dos Atingodos por Barragens. https://mab.org.br/lutas/

Mahesh, Uniyal: First international meet of anti-dam movements. Inter Press Service News Agency North America, 1997, 1-2.

Massara, Vanessa Meloni: The use of hydroelectric plants in Brazil - Brief overview. MOJ Civil Engineering, Vol. 5, 2019, 81-82. DOI: 10.15406/mojce.2019.05.00154

McCormick, Sabrina: The brazilian anti-dam movement. Knowledge Contestation as Communicative Action, Organization \& Environment, Vol. 19, 2006/3., 321-346. DOI: 10.1177/1086026606292494

Ministério do Meio Ambiente: Água. https://www.mma.gov.br/agua

Monthly energy bulletin. Brazil Ministry of Mines and Energy - MME, Secretariat of Energy Planning and Development - SPE, Department of Information and Studies On Energy - DIE, 04. 2020.

Movimento dos Atingidos por Barragens, I. Congresso Nacional Dos Atingidos Por Barragens. https:// mab.org.br/timeline/i-congresso-nacional-dos-atingidos-por-barragens/

Neves, Mateus Machado: Difficulties in expanding hydropower generation in Brazil. The George Washington University - The School Of Business and Public Management - The Institute Of Brazilian Issues, Washington, 2009.

Nickson, Andrew: The Itaipú Hydro-Electric Project: The Paraguayan Perspective. Bulletin of Latin American Research, Vol. 2, 1982/1., 1-20.

Oliveira, Adilson de: Energy Security in South America. The role of Brazil. Series on Trade and Energy Security. International Institute for Sustainable Development, Winnipeg, 2010.

Pela primeira vez, fomos reconhecidos enquanto atingidos por um presidente. https://mab.org.br/time line/pela-primeira-vez-fomos-reconhecidos-enquanto-atingidos-por-um-presidente/

Potencial Hidrelétrico Brasileiro (SIPOT). https:/eletrobras.com/pt/AreasdeAtuacao/geracao/sipot/ MapaSipot-Dezembro2018.pdf

Potencial Hidrelétrico Brasileiro em cada Estágio por Regiões (valores em MW), Eletrobras. https://eletro bras.com/pt/AreasdeAtuacao/geracao/sipot/Potencial\%20Hidrel\%C3\%A9trico\%20Brasileiro\%20 por\%20Regi\%C3\%A3o\%20-\%20Dezembro\%202018.pdf

Relatório de Classificação das Barragens (Ciclo 2019). ANEEL - Agência Nacional de Energia Elétrica. https:/www.aneel.gov.br/documents/655816/14881864/Relat\%C3\%B3rio+de+Classifica\%C3\%A7 $\% \mathrm{C} 3 \% \mathrm{~A} 3 \mathrm{o}+\mathrm{de}+$ Seguran $\% \mathrm{C} 3 \% \mathrm{~A} 7 \mathrm{a}+\mathrm{de}+$ Barragens+-+Ciclo+2019/56cb6597-dd2b-d64a-f369-6caa 3aeaf897

Riberio, Heidi Michalski - Morato, Jose Rubens: Social environmental injustices against indigenous peoples: The Belo Monte dam. Disaster Prevention and Management, 2020/6. DOI: 10.1108/DPM02-2020-0033

Schachet, Carol: Say Their Names: Sajed Mizher, Presente. Grassroots International, 2019. 03. 20. https:// grassrootsonline.org/blog/say-their-names-sajed-mizher-presente/

Sobre as Mulheres Atingidas por Barragens. https://mab.org.br/mulheres/

Soltész Béla: Brazília. In: Szente-Varga Mónika - Bács Zoltán György (szerk.): Dél-Amerika a 21. században - Társadalmi, gazdasági és politikai konfliktusok. Dialóg Campus Kiadó, Budapest, 2019, $41-57$.

Szente-Varga Mónika: Brazília az olimpia elött. Nemzet és Biztonság, 2016/ 3., 11-124.

Szeredi István - Alföldi László - Csom Gyula - Mészáros Csaba: A vizenergia-hasznositás szerepe, helyzete, hatásai. Magyar Tudomány, 2010/ 8., 959-978.

Dr. Szlivka Ferenc - Dr. Molnár Ildikó: Víz- és szélenergia hasznosítás. Edutus Főiskola, 2011.

Tempering the human cost of building Brazil's dams. Instituto Igarapé, 29. 06. 2017. https://igarape. org.br/en/tempering-the-human-cost-of-building-brazils-dams/ 
The history of MAB. Movimento dos Atingidos por Barragens, 26. 03. 2011. https://mab.org.br/ 2011/03/26/history-mab/

The world's most used renewable power sources. Power Technology, 06. 01. 2020. https://www.powertechnology.com/features/featurethe-worlds-most-used-renewable-power-sources-4160168/

Thorkildsen, Kjersti: Land yes, dam no!' Justice-seeking strategies by the anti-dam movement in the Ribeira Valley, Brazil. The Journal of Peasant Studies, 2016, 1-22. DOI: 10.1080/03066150. 2016.1217842

Xavier, Marcus Renato S.: The Brazilien Sugarcane Ethanol Experience. Competitive Enterprise Institute, Issue Analysis, 2007/ 3., 1-13.

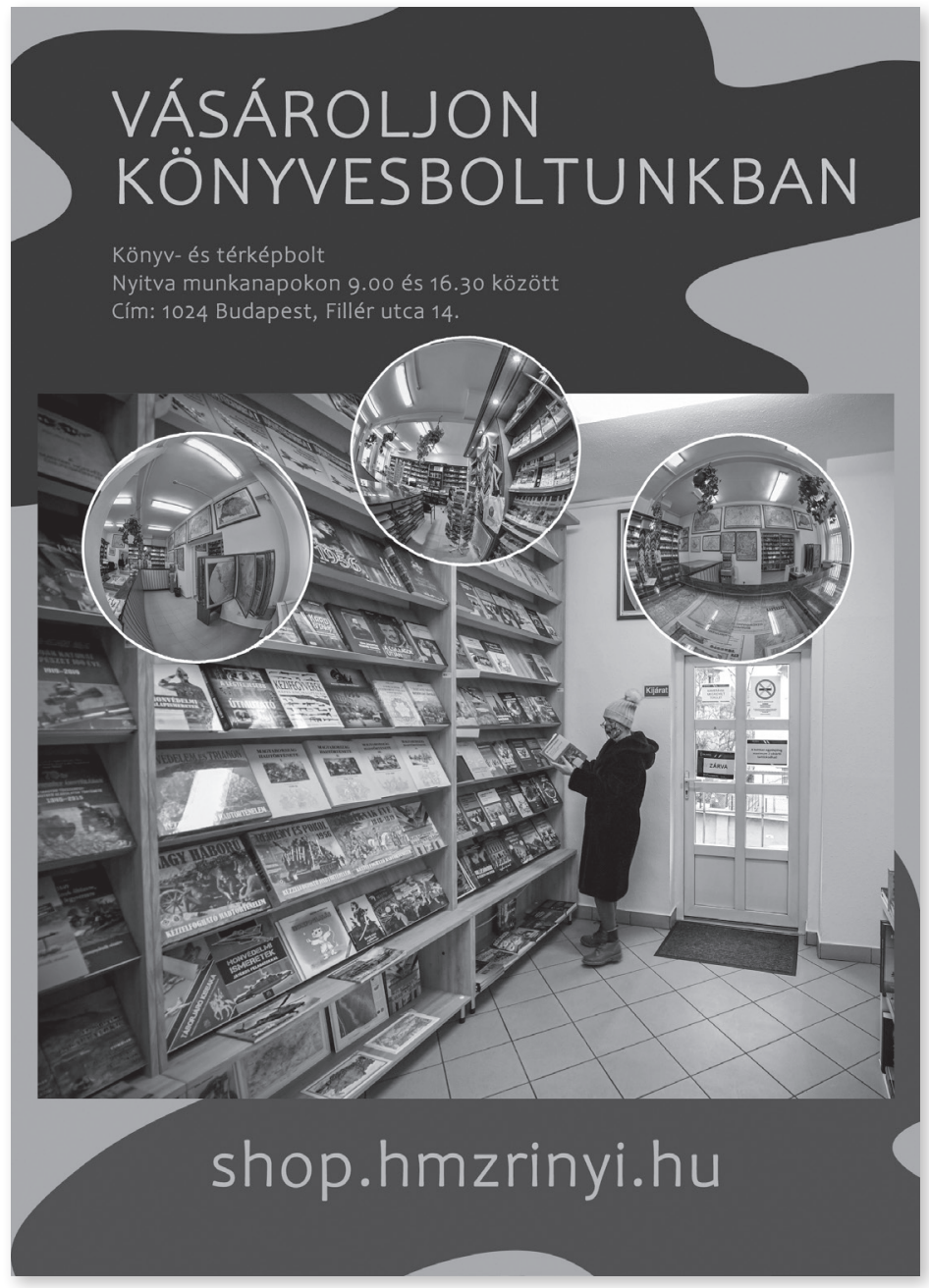

